\title{
EFFECT OF DIETARY SUPPLEMENTATION OF CINNAMON AND CURCUMIN ON PERFORMANCE, CARCASS TRAITS, HUMORAL IMMUNE RESPONSES, AND BLOOD SERUMMETABOLITES IN GROWING RABBITS
}

\author{
H.S. Zeweil; S.M. Zahran; M. H. Ahmed; Y.M. El-Gindy and N.S.M. Khoshera \\ Department of Animal and Fish Production, Faculty of Agriculture (Saba Basha), Alexandria University.
}

(Received 20/11/2016, Accepted 29/12/2016)

\section{SUMMARY}

\begin{abstract}
$\mathrm{A}$ total of seventy-two V-line rabbits of both sexes, 5 weeks old, with initial weights of $639.4 \pm .25 .97 \mathrm{~g}$ were used for the study. Rabbits were randomly allocated to 6 treatment groups, each of which included 4 replicates of 3 rabbits. The experiment lasted for 6 weeks to be finished at 11 weeks of age and dietary treatments were as follows: 1) Control (basal diet); 2) basal diet+ $100 \mathrm{mg} / \mathrm{kg}$ antibiotictylosin; 3) basal diet+ $0.5 \mathrm{~g} / \mathrm{kg}$ turmeric (as a source of curcumin); 4) basal diet+ $1.0 \mathrm{~g} / \mathrm{kg}$ turmeric; 5) basal diet+ $0.5 \mathrm{~g} / \mathrm{kg}$ cinnamon; 6) basal diet $+1.0 \mathrm{~g} / \mathrm{kg}$ cinnamon. The results showed that there were significant $(\mathrm{P} \leq 0.05)$ differences in body weight, weight gain, feed intake and feed conversion ratio among treatments and the control group. The highest body weight and weight gain values and the best feed conversion ratio were recorded in the groups given $1.0 \mathrm{~g} / \mathrm{kg}$ diet turmeric or cinnamon. The highest feed intake values were observed in the control and Tyrosin fed groups, while the lowest feed intake values was recorded in cinnamon fed group. Tylosin, cinnamon and turmeric supplementation significantly $(\mathrm{P} \leq 0.05)$ improved digestibility of $\mathrm{DM}, \mathrm{OM}, \mathrm{CP}, \mathrm{CF}, \mathrm{EE}$ and NFE and also, improved the nutritive values of nutrients as TDN and DCP in comparison with control. General significant $(\mathrm{P} \leq$ 0.05) increase in RBCs, $\mathrm{Hb}$ and PCV \% due to the different feed additives in comparison with control group. Serum lipid profile improved by phytogenic feed additives compared with tylosin and control groups. Phytogenic feed additives reduced Malondialdehyde $(\mathrm{P} \leq 0.05)$, while, increased total antioxidant capacity concentrations and glutathione peroxidase activities. Immunostimulatory effects of phytogenic feed additives were recorded. In conclusion, we state that cinnamon and turmeric could have beneficial effects on performance, digestibility, immunomodulatory and play an important role as an exogenous antioxidant.
\end{abstract}

Keywords: Rabbits, cinnamon and turmeric, antibiotic, performance, immunity and blood lipid profile.

\section{INTRODUCTION}

Large numbers of feed additives are available for inclusion in animal and poultry diets to improve animal performance. Recently, many countries tend to prevent the application of antibiotics for their side effects. The ban on nutritive antibiotic use in the world and the augmented awareness of the consumers triggered a need for natural and safe feed additives to achieve better production results of farm animals therefore, nowadays growth promoters from herbal sources (phytogenic extracts) are used very commonly (Zeweil et al., 2016). The use of phyto-additives and their extracts in rabbit husbandry offers an acceptable way to improve welfare and health s (Szabóováet al. 2008)

Turmeric is a yellow powder driven from the rhizome of "Curcuma longa" with extensive use as spices particularly in south \&south-east Asia and Middle East countries. Curcumin, the yellow pigment of turmeric, the main active component in turmeric (Jagetia andAggarwal, 2007). Antioxidative properties have been reported for turmeric and curcumin in several studies (Reddy and Lokesh, 1994; Wei and Shibamoto, 2007). Also, it has been shown that turmeric and curcumin possesshypolipidemic effects (Dixit et al., 1988; Babu and Srinivasan, 1997). Antiinflammatory and immune system modulating effects of turmeric (Joe et al., 1997; South et al., 1997).

Cinnamaldehyde is the major component of cinnamon, creating about 65 percent of the extracted essential oil (Mountzouriset al., 2009). Immune system stimulating effects has been reported for cinnamaldehyde (Nofrariaset al., 2006). Also, considerable antibacterial (Tabak et al., 1999; Chang et al., 
Rabbits were housed in well ventilated block building. Fresh air circulated in the house using exhaust fans. The rabbits were kept within a cycle of $16 \mathrm{~h}$ light and $8 \mathrm{~h}$ dark. Antibiotic tyrosin was obtained from Chemical Industries Development (CID) El-Tlbia-Pyramids-Giza-A.R.E-G.C.R19717- Giza, Egypt).Cinnamon and turmeric were obtained from Imtenan Health Shop, 20 Mohamed Bahaa El-Din El-Ghatory, Semouha, Alexandria, Egypt). Individual body weight and feed consumption were recorded weekly. Body weight gain and feed conversion ratio were calculated. The incidence of dangerous diseases was largely avoided and rabbits have never been treated with any kind of systematic vaccination or medication. Mortality rate was recorded as a number of dead animals in each group during the whole experimental period and percentage calculated.

Three rabbits per treatment were housed individually in the digestibility cage for 7 days to collect feces and urine. Shaded hair or non-fecal materials were eliminated. Feces and urine were collected quantitatively daily morning, and weight fresh and stored at $4^{\circ} \mathrm{C}$ in a refrigerator. The seven days combined collection were sampled and kept for analysis. Fecal samples were dried at $60{ }^{\circ} \mathrm{C}$ for $72 \mathrm{~h}$. Feeds and fecal samples were 1 $\mathrm{mm}$ screen grinded by a wiley mill grinder and the samples $(20 \mathrm{~g} / \mathrm{sample} / \mathrm{treatment} / \mathrm{rabbit})$ were analyzed. The samples of feed and feces were analyzed for crude protein (CP), crude fiber (CF), ether extract (EE) and ash were analyzed according to AOAC (2005). Values of the total digestible nutrients (TDN; DCP) were calculated according to the classic formula of Cheekeet al. (1987) on a dry matter basis from feed and fecal samples content of dry matter (DM).

At the end of the feeding trial, 3 rabbits were selected from each treatment group randomly, starved of food but not water for 12 hours and slaughtered for carcass analysis. Before slaughtering, $6 \mathrm{ml}$ of blood sample was taken from the ear vein with a sterile syringe. $3 \mathrm{ml}$ of the blood was put into a bijon bottle containing ethylene diaminetetracetic acid (EDTA) as an anticoagulant for hematological assay. The remaining $3 \mathrm{ml}$ of the blood sample was put into a sterile vacutainer tube without an anticoagulant for serum biochemical analysis. The hematological assay was carried out to determine erythrocyte indices such as packed cell volume (PCV), and hemoglobin $(\mathrm{Hb})$ values. Red blood cell $(\mathrm{RBC})$ counts were counted on an AO Bright line hemocytometer using a light microscope at 400X magnification after diluting blood samples 200 times with a physiological saline $(0.9 \% \mathrm{NaCl}$ solution) before counting (Natt and Herrick, 1952). White blood cell (WBC) were counted on an AO Bright line hemocytometer using a light microscope with a little of Leishman's stain) before counting (Hepler, 1966). Total lipids, triglycerides, total cholesterol, low density lipoprotein (LDL), high density lipoprotein (HDL), total antioxidant capacity (TAC), lipid peroxidase (MAD) and glutathione peroxidase (GP) concentrations in serum were estimated using commercial kits (Bio Merieux, France) according to the procedure outlined by the manufacturer. Serum immunoglobulin IgG was determined using ELISA technique. Three rabbits of each treatment were immunized with $0.1 \mathrm{ml}$ of a $2.5 \%$ Sheep Red Blood Cells (SRBCs) via the marginal ear vein at 15 days after starting the dietary treatment supplementation, to measure antibody titer against sheep red blood cells. The dosage of SRBC for inoculation was pre-determined by a separate trial. Antiserum to SRBCs was collected14days post challenge according to Wegmann and Smithies, (1966). The agglutination titer was expressed as the $\log ^{2}$ of the reciprocal of the highest serum dilution giving complete agglutination (Nelson et al., 1995). The results were expressed as the mean \pm SE All data were analyzed using one way analysis of variance (ANOVA) using SPSS 11.0 statistical software (SPSS, Inc., Chicago, Il, 2001). Significant differences between means were detected using new Duncan multiple range test (Duncan, 1955).The differences among mortality rate were tested by chi-square.

\section{RESULTS AND DISCUSSION}

There were significant $(\mathrm{P} \leq 0.05)$ differences in body weight, weight gain, feed intake and feed conversion ratio among treatments and the control group (Table 2). The highest body weight and the best feed conversion ratio were recorded in the groups given $1.0 \mathrm{~g} / \mathrm{kg}$ turmeric or cinnamon. Besides, the highest weight gain value was found in the group given $1.0 \mathrm{~g}$ cinnamon/ $\mathrm{kg}$ diet. Furthermore, the lowest final body weight and weight gain and the poorest feed conversion ratio were found in the control group. Moreover, the highest feed intake values were observed in the control and tyrosin groups, while the lowest feed intake values was recorded in cinnamon fed group. In fact, mortality percent was not different among the groups that may be due to good hygienic condition of the farm and good sanitary status of the digestive system. 
The improvement in performance of rabbits with phytogenic additives may be also due to providing some compounds that enhance digestion and absorption of some nutrients in the diets, that may be attributed to the bioactive components (curcuminoidscurcumin and cinnamal-dehyde and ugenol) found in turmeric and cinnamon that cause greater efficiency in the utilization of feed, resulting in enhanced growth.

The most efficient feed conversion ratio in rabbits fed diets supplemented with antibiotic, turmeric and cinnamon powder reveals that the impact of growth promoter substances may be related to a more efficient use of nutrients. Cinnamon and turmeric improved the performance that may be due to reduced levels of peroxidation (blood serum MDA), and or due to the active components that enhance digestion and absorption of dietary nutrients. The results presented by Hussein (2012) reported that curcuminoids and curcumin of turmeric increased utilization of feed, resulting in enhanced growth. Turmeric extract demonstrated high potential to inhibit some pathogenic bacteria of chicken (Ong-ardet al., 2010). Cinnamon has strong antibacterial properties, anticandidial, antiulcer, analgesic, antioxidant and hypocholesterolaemic activities (Masturaet al., 1999; Shihabudeenet al., 2011). The essential oil from Cinnamomumzeylanicumbark is rich in trans-cinnamaldehyde with antimicrobial effects against animal pathogens (Mastura et al., 1999). Thus, alike antibiotics, turmeric and cinnamon may control and limit the growth and colonization of numerous pathogenic and non-pathogenic species of bacteria in chickens' gut resulting in balanced gut microbial ecosystems that leads to better feed utilization reflected by improved feed conversion ratio. Corresponding to our results on feed efficiency, Durraniet al. (2006) also reported that chickens receiving diets supplemented with $5 \mathrm{~g} / \mathrm{kg}$ turmeric powder had better feed conversion ratio than 2.5 and $10 \mathrm{~g} / \mathrm{kg}$ supplementation level. Our results were in agreement with those of Wuthi-Udomler et al. (2000) and Samarasingheet al. (2003) who found that birds fed turmeric powder had lower feed intake and feed conversion ratio in comparison with control. However, the present results were in disagreement with those of Peirettiet al. (2011) who found that the growth performance parameters of growing rabbits were not affected by dietary curcuma supplementation $(3 \mathrm{~g} / \mathrm{kg}$ diet). Also, Basavarajet al. (2010) showed addition of turmeric150, $300 \mathrm{mg}$ to rabbit's diet did not affect the body weight gain and feed intake. Naderi et al. (2014) reported that feed intake of broilers was not affected by any of the dietary additives (avilamycin, turmeric powder $2.5 \mathrm{~g} / \mathrm{kg}$, or cinnamon powder $7.5 \mathrm{~g} / \mathrm{kg}$ diet) during different periods of the experiment. Also, Song-oh et al. (2013) found insignificant effect on feed intake due to inclusion of cinnamon in the diet in comparison with control. El-Kholyet al. (2012) reported that rabbits fed the cinnamon supplemented diet $(500 ; 1000$ and $1500 \mathrm{~g} /$ Ton diet) had significant increase at 60 days in final body weight; daily weight gain and feed intake and feed efficiency values compared to the control group.

In general, antibiotic tylosin, cinnamon and turmeric supplementation significantly $(\mathrm{P} \leq 0.05)$ improved digestibility of DM, OM, CP, CF, EE and NFE in comparison with control (Table 3). Digestion coefficients of dry matter, organic matter, crude protein and ether extract were the best in the groups had $1.0 \mathrm{~g} / \mathrm{kg}$ turmeric, 0.5 and $1.0 \mathrm{~g} / \mathrm{kg}$ cinnamon in comparison with control, tylosin and $0.5 / \mathrm{kg}$ turmeric treatments. The results showed also that tylosin and $0.5 \mathrm{~g} / \mathrm{kg}$ turmeric significantly $(\mathrm{P} \leq 0.05)$ exceed the control group in the aforementioned traits. There is evidence to suggest that herbs, spices, and various plant extracts have appetiteand digestion-stimulating properties and antimicrobial effects (Kamel, 2001). Plant extracts contain different molecules that have intrinsic bioactivities on animal physiology and metabolism. The mechanisms by which these products influence the gut microflora and growth performance of poultry are not known. The plant extract clearly demonstrate antibacterial properties, although the mechanistic processes are poorly understood (Dorman and Deans, 2000). Al-Sultan and Gameel (2004) reported that curcumin can accelerate the emulsification of fat by stimulating the production of bile so that the digestion of fat will be more optimal. Astawaet al. (2016) showed that the digestibility coefficient of organic matter and crude protein was the best in turmeric extract at $0.04 \mathrm{ml} / \mathrm{kg}$ body weight than the groups received $0.02 \mathrm{ml}$ of turmeric extract $/ \mathrm{kg}$ body weight compared to the control group. The results obtained were significantly different because turmeric extract may increase the production and secretion of bile into the small intestine so that digestion of fats, protein, and carbohydrates increased.

Total digestible nutrients (TDN) and digestible crude protein (DCP) were significantly $(\mathrm{P} \leq 0.05)$ improved by the different feed additives in comparison with the control group. The best value of TDN was record in the group supplemented with $1.0 \mathrm{~g} / \mathrm{kg}$ cinnamon. However, the best value of DCP was record in the groups had 0.5 and $1.0 \mathrm{~g} / \mathrm{kg}$ cinnamon, 0.5 and $1.0 \mathrm{~g} / \mathrm{kg}$ turmeric (Table 3 ). 
Table (2). Effect of tylosin, turmeric and cinnamon on growing $\mathrm{V}$-line rabbits performance.

\begin{tabular}{|c|c|c|c|c|c|c|}
\hline \multirow[t]{2}{*}{ Characteristics } & \multirow{2}{*}{ Control } & \multirow{2}{*}{$\begin{array}{c}\text { Tylosin } \\
100 \mathrm{mg} / \mathrm{kg}\end{array}$} & \multicolumn{2}{|c|}{ Turmeric $(\mathrm{g} / \mathrm{kg})$} & \multicolumn{2}{|c|}{ Cinnamon $(\mathrm{g} / \mathrm{kg})$} \\
\hline & & & 0.5 & 1.0 & 0.5 & 1.0 \\
\hline Initial body weight, $g$ & $630.20 \pm 29.51$ & $633.42 \pm 27.90$ & $636.81 \pm 27.32$ & $645.73 \pm 15.43$ & $638.92 \pm 29.3$ & $651.24 \pm 26.39$ \\
\hline Final body weight, g & $1887.93^{\mathrm{d}} \pm 54.53$ & $1969.70^{\mathrm{c}} \pm 44.81$ & $1999.90^{\mathrm{b}} \pm 42.1$ & $2135.21^{\mathrm{a}} \pm 32.7$ & $1993.92^{\mathrm{b}} \pm 52.20$ & $2154.61^{\mathrm{a}} \pm 58.20$ \\
\hline Total weight gain, g & $1257.62^{\mathrm{e}} \pm 21.42$ & $1336.32^{\mathrm{d}} \pm 22.74$ & $1363.10^{\mathrm{c}} \pm 19.7$ & $1489.51^{b} \pm 20.70$ & $1355.01^{\mathrm{c}} \pm 22.4$ & $1503.40^{\mathrm{a}} \pm 24.73$ \\
\hline Total feed intake, $\mathrm{g}$ & $3559.50^{\mathrm{a}} \pm 79.21$ & $3521.71^{\mathrm{a}} \pm 101.22$ & $3474.63^{\mathrm{b}} \pm 98.10$ & $3447.8^{c} \pm 98.21$ & $3381.44^{\mathrm{d}} \pm 96.02$ & $3388.01^{\mathrm{d}} \pm 97.13$ \\
\hline Feed conversion ratio & $2.83^{\mathrm{a}} \pm 0.03$ & $2.63^{b c} \pm 0.10$ & $2.54^{\mathrm{c}} \pm 0.08$ & $2.31^{\mathrm{d}} \pm 0.09$ & $2.49^{\mathrm{c}} \pm 0.02$ & $2.25^{\mathrm{d}} \pm 0.04$ \\
\hline No of dead rabbits $(\%)$ & $2 / 12(16.7 \%)$ & $0 / 12(0 \%)$ & $1 / 12(8.33 \%)$ & $1 / 12(8.33 \%)$ & $0 / 12(0 \%)$ & $1 / 12(8.33 \%)$ \\
\hline
\end{tabular}

Different letters $(a-d)$ within a row denote significant differences between treatments $(P \leq 0.05)$.

Table (3). Effect of tylosin, turmeric and cinnamon on growing V-line rabbits digestibility coefficients.

\begin{tabular}{|c|c|c|c|c|c|c|}
\hline \multirow[t]{2}{*}{ Characteristics } & \multirow{2}{*}{ Control } & \multirow{2}{*}{$\begin{array}{c}\text { Tylosin } \\
100 \mathrm{mg} / \mathrm{kg}\end{array}$} & \multicolumn{2}{|c|}{ Turmeric $(\mathrm{g} / \mathrm{kg})$} & \multicolumn{2}{|c|}{ Cinnamon $(\mathrm{g} / \mathrm{kg})$} \\
\hline & & & 0.5 & 1.0 & 0.5 & 1.0 \\
\hline \multicolumn{7}{|l|}{ Digestibility of } \\
\hline Dry matter, $\%$ & $66.07^{\mathrm{c}} \pm 1.09$ & $71.66^{\mathrm{b}} \pm 1.18$ & $69.13^{\mathrm{b}} \pm 1.23$ & $73.05^{\mathrm{a}} \pm 1.15$ & $73.89^{\mathrm{a}} \pm 1.12$ & $74.27^{\mathrm{a}} \pm 1.06$ \\
\hline Organic matter, $\%$ & $89.10^{\mathrm{c}} \pm 1.67$ & $91.52^{\mathrm{a}} \pm 1.52$ & $90.50^{\mathrm{b}} \pm 1.54$ & $92.75^{\mathrm{a}} \pm 1.56$ & $92.05^{\mathrm{a}} \pm 1.59$ & $92.90^{\mathrm{a}} \pm 1.32$ \\
\hline Crude protein, $\%$ & $62.17^{\mathrm{c}} \pm 1.16$ & $65.94^{\mathrm{b}} \pm 1.15$ & $64.99^{\mathrm{b}} \pm 1.18$ & $70.97^{\mathrm{a}} \pm 1.20$ & $70.04^{\mathrm{a}} \pm 1.19$ & $72.54^{\mathrm{a}} \pm 1.23$ \\
\hline Crude fiber, $\%$ & $42.84^{\mathrm{c}} \pm 1.09$ & $48.00^{\mathrm{b}} \pm 1.04$ & $45.42^{b} \pm 1.02$ & $52.52^{\mathrm{a}} \pm 1.13$ & $53.03^{\mathrm{a}} \pm 1.10$ & $53.15^{\mathrm{a}} \pm 1.07$ \\
\hline Ether extract, \% & $46.19^{c} \pm 2.09$ & $51.61^{\mathrm{a}} \pm 2.20$ & $48.83^{b} \pm 2.12$ & $51.14^{\mathrm{a}} \pm 2.21$ & $50.56^{\mathrm{a}} \pm 2.19$ & $52.48^{\mathrm{a}} \pm 2.23$ \\
\hline Nitrogen free extract, $\%$ & $55.60^{\mathrm{b}} \pm 1.89$ & $59.62^{\mathrm{a}} \pm 1.73$ & $58.40^{\mathrm{a}} \pm 1.85$ & $59.75^{\mathrm{a}} \pm 1.46$ & $59.15^{\mathrm{a}} \pm 1.52$ & $59.80^{\mathrm{a}} \pm 1.48$ \\
\hline \multicolumn{7}{|l|}{ Nutritive values } \\
\hline TDN\% & $55.71^{\mathrm{c}} \pm 0.23$ & $62.80^{b} \pm 0.21$ & $59.24^{\mathrm{b}} \pm 0.24$ & $60.08^{b} \pm 0.28$ & $61.39^{b} \pm 0.30$ & $64.38^{\mathrm{a}} \pm 0.19$ \\
\hline $\mathrm{DCP}$ & $10.84^{\mathrm{c}} \pm 0.07$ & $11.49^{b} \pm 0.06$ & $11.37^{\mathrm{b}} \pm 0.12$ & $12.41^{\mathrm{a}} \pm 0.08$ & $12.20^{\mathrm{a}} \pm 0.13$ & $12.67^{\mathrm{a}} \pm 0.17$ \\
\hline
\end{tabular}


Results for hematological parameters of the rabbits in Table (4) showed that all hematological parameters at control group were significantly decreased through the Egyptian summer season; however, a general significant $(\mathrm{P} \leq 0.05)$ increase in $\mathrm{RBCs}, \mathrm{WBCs}, \mathrm{Hb}$ and $\mathrm{PCV} \%$ due to the different feed additives in comparison with control group was observed. One of the mechanisms to dissipate heat from the body is by panting (thermal panting) increased respiratory rate with a decreased tidalvolume (Ludders, 2004). Study by Comito et al. (2007) reported that thermal panting could decrease hemoglobin synthesis. Curcumin in turmeric can accelerate the emulsification of fat by stimulating the production of bile (Al-Sultan and Gameel, 2004)so that the digestion of fat will be more optimal. Optimized fat digestion will indirectly increase the provision of substrates for ß-oxidation or fat metabolism which eventually enhances the production of succinyl-CoA through Krebs metabolic cycle (Cunningham and Klein, 2007).Considering succinyl-CoA is one of the materials needed for hemoglobin (heme in particular) synthesis (Bunn and Forget, 1986), enhancedsuccinyl-CoA production was therefore most likely to be followed by the increase of hemoglobin synthesis. The principal component of erythrocytes is hemoglobin, which makes up about one-third of the erythrocytes content (Reece, 2009). Thus, enhanced hemoglobin concentration due to turmeric extract should be followed by the enhanced erythrocytes concentration. Hematocrit measures the percentage of the volume of whole blood that is made up of red blood cells (Reece, 2009). Hematocrit is strongly affected by red blood cells concentration in the blood. Thus, alongside with the concentration of erythrocytes, turmeric having significant effect $(\mathrm{P} \leq 0.05)$ on hematocrit level (Table 4$)$ could be accepted. In disagreement with the present results, Baghban et al. (2016) showed that turmeric and cinnamon either alone or together did not change levels of hematocrit. Similarly, Hosseini-Vashanet al. (2012) reported no changes in hemoglobin and hematocrit values of broilers fed up to $8 \mathrm{~g} / \mathrm{kg}$ turmeric powder.

The normal PCV indicates the absence of normocytic anemia which is reportedly characterized by normal MCV and MCH and only detected by a decreased number of RBCs or PCV (Coles, 1986). The result is corroborated by the normal RBCs which further elucidated the absence of hemolytic anemia and depression of erythrogenesis. The normal hemoglobin concentration for all the experimental rabbits is probably an indication that these feed additives supplement supported hemoglobin synthesis, (Sirosis, 1995) is among other factors, primarily affected by protein intake or may be due to iron deficiency and its improper utilization for the formation of hemoglobin (Ogbuewuet al., 2013). Njiddaet al. (2006) reported that normal range of values for $\mathrm{Hb}$ indicated that the vital physiological relationship of hemoglobin with oxygen in the transport of gases (oxygen and carbon dioxide) to or from the tissues of the body has been maintained and was normal. Emadi et al. (2007) demonstrated that turmeric supplementation into the basal diets of broilers did not affect haematocrit value at 42 days of age.

Determined antibody titters against SRBCs are shown in Table (4) as affected by different feed additives. The different phytogenic feed additives significantly $(\mathrm{P} \leq 0.05)$ increased antibody titters against SRBCs compared with control and tylosin fed groups after 14days of vaccination. This may be attributed to that, the use of different phytogenic feed additives eleminate immune response against some diseases. Serum IgG was enhanced $(\mathrm{P} \leq 0.05)$ in rabbits fed diets containing phytogenic additives and tylosin in comparison with control. However, the effect of phytogenic additives was more pronounced than tylosin. Cinnamon and turmeric addition may improve the immune system due to the increase in the immunoglobulin concentrations ( $\operatorname{IgG})$ of rabbits versus the control and tylosin containing diet. It is shown that cinnamon and turmeric were significantly an immunomodulatory. It was observed by Kumariet al. (2007) that supplementation of broilers diets with turmeric increased serum $\mathrm{Zn}$ concentration which can be related to increased antioxidant defense. Also Churchill et al. (2000) reported that an increase in CD4 T-lymphocytes as well as B-lymphocytes in mice consuming 1 gram curcumin per kilogram of the diet. Immunostimulatory effects of turmeric have been demonstrated by Chandrasekaran et al. (2013). The study of Song-Oh et al. (2013) reported that the IgG, IgA and IgM levels of the cinnamon powder fed groups were significantly higher than control group. Specifically, in $5 \%$ cinnamon powder fed group which represented the greatest increase when compared with control. Also, Sadeghiet al. (2012) reported that cinnamon infusion improved antibody titers against Newcastle disease virus (NDV) in comparison to control group.

Results illustrated in Table (5) showed the effect of different treatments on blood serum lipid profile. It was observed that serum total lipids, triglycerides, total cholesterol and low density lipoprotein (LDL) significantly $(\mathrm{P} \leq 0.05)$ decreased with different levels of cinnamon and turmeric in comparison with the group received tylosin in their diet and control group. On the other hand, high density lipoprotein (HDL) concentration was significantly $(\mathrm{P} \leq 0.05)$ increased in the groups fed cinnamon and turmeric as compared with tylosin and control fed groups. 
Egyptian J. Nutrition and Feeds (2016)

Table (4). Effect of tylosin, turmeric and cinnamon on growing V-line rabbits blood hematology, antibody titers and serum IgG.

\begin{tabular}{|c|c|c|c|c|c|c|}
\hline \multirow[t]{2}{*}{ Characteristics } & \multirow{2}{*}{ Control } & \multirow{2}{*}{$\begin{array}{c}\text { Tylosin } \\
100 \mathrm{mg} / \mathrm{kg}\end{array}$} & \multicolumn{2}{|c|}{ Turmeric (g/kg) } & \multicolumn{2}{|c|}{ Cinnamon $(\mathrm{g} / \mathrm{kg})$} \\
\hline & & & 0.5 & 1.0 & 0.5 & 1.0 \\
\hline \multicolumn{7}{|l|}{ Hematology } \\
\hline $\operatorname{RBC}\left(\times 10^{6} / \mathrm{mm}^{3}\right)$ & $4.72^{b} \pm 0.38$ & $5.79^{\mathrm{a}} \pm 0.14$ & $5.83^{\mathrm{a}} \pm 0.23$ & $5.98^{\mathrm{a}} \pm 0.47$ & $5.73^{\mathrm{a}} \pm 0.16$ & $5.84^{\mathrm{a}} \pm 0.33$ \\
\hline $\mathrm{HB}(\mathrm{g} / 100 \mathrm{ml})$ & $9.00^{b} \pm 0.58$ & $11.16^{\mathrm{a}} \pm 0.17$ & $11.00^{\mathrm{a}} \pm 0.40$ & $11.37^{\mathrm{a}} \pm 0.97$ & $11.42^{\mathrm{a}} \pm 0.22$ & $11.39^{\mathrm{a}} \pm 0.49$ \\
\hline $\operatorname{PCV}(\%)$ & $31.43^{\mathrm{b}} \pm 1.23$ & $34.03^{\mathrm{a}} \pm 0.8$ & $34.40^{\mathrm{a}} \pm 1.15$ & $34.33^{\mathrm{a}} \pm 2.39$ & $34.30^{\mathrm{a}} \pm 0.49$ & $34.93^{\mathrm{a}} \pm 1.10$ \\
\hline $\mathrm{WBC}\left(\times 10^{3} / \mathrm{mm}^{3}\right)$ & $3.42^{\mathrm{b}} \pm 1.09$ & $3.53^{b} \pm 0.46$ & $5.46^{\mathrm{a}} \pm 0.73$ & $5.54^{\mathrm{a}} \pm 0.27$ & $5.48^{\mathrm{a}} \pm 0.28$ & $5.63^{\mathrm{a}} \pm 0.72$ \\
\hline \multicolumn{7}{|c|}{ Antibody titers and serum $\operatorname{Ig} G$} \\
\hline SRBCs at 14 day & $0.694^{\mathrm{c}} \pm 0.01$ & $0.724^{\mathrm{c}} \pm 0.03$ & $0.908^{b} \pm 0.02$ & $0.953^{\mathrm{a}} \pm 0.04$ & $0.963^{\mathrm{a}} \pm 0.02$ & $0.968^{\mathrm{a}} \pm 0.03$ \\
\hline Serum IgG $(\mathrm{mg} / \mathrm{dl})$ & $209.6^{\mathrm{c}} \pm 5.781$ & $246.7^{\mathrm{bc}} \pm 27.28$ & $285.0^{\mathrm{b}} \pm 10.41$ & $298.3^{\mathrm{ab}} \pm 12.02$ & $340.0^{\mathrm{a}} \pm 17.32$ & $341.3^{\mathrm{a}} \pm 18.89$ \\
\hline
\end{tabular}

Different letters $(a-c)$ within a row denote significant differences between treatments $(P \leq 0.05)$.

Table (5). Effect of tylosin, turmeric and cinnamon on growing $V$-line rabbits blood serum lipid profile and antioxidant status.

\begin{tabular}{|c|c|c|c|c|c|c|}
\hline \multirow[t]{2}{*}{ Characteristics } & \multirow{2}{*}{ Control } & \multirow{2}{*}{$\begin{array}{c}\text { Tylosin } \\
100 \mathrm{mg} / \mathrm{kg}\end{array}$} & \multicolumn{2}{|c|}{ Turmeric $(\mathrm{g} / \mathrm{kg})$} & \multicolumn{2}{|c|}{ Cinnamon (g/kg) } \\
\hline & & & 0.5 & 1.0 & 0.5 & 1.0 \\
\hline \multicolumn{7}{|l|}{ Serum lipid profile } \\
\hline Total lipids (mg/dl) & $247.00^{\mathrm{a}} \pm 10.11$ & $229.00^{\mathrm{b}} \pm 4.41$ & $212.00^{\mathrm{c}} \pm 7.62$ & $204.00^{c} \pm 6.43$ & $205.00^{\mathrm{c}} \pm 6.84$ & $201.00^{c} \pm 6.56$ \\
\hline Triglycerides (mg/dl) & $55.66^{\mathrm{a}} \pm 1.15$ & $54.02^{\mathrm{a}} \pm 2.51$ & $53.00^{\mathrm{b}} \pm 1.00$ & $52.33^{\mathrm{b}} \pm 0.33$ & $52.00^{\mathrm{b}} \pm 0.58$ & $52.00^{\mathrm{b}} \pm 1.20$ \\
\hline Cholesterol (mg/dl) & $93.66^{a} \pm 0.66$ & $94.12^{\mathrm{a}} \pm 4.84$ & $72.13^{\mathrm{b}} \pm 1.15$ & $71.00^{\mathrm{b}} \pm 4.70$ & $73.15^{\mathrm{b}} \pm 4.81$ & $76.00^{\mathrm{b}} \pm 2.00$ \\
\hline $\mathrm{HDL}(\mathrm{mg} / \mathrm{dl})$ & $33.66^{b} \pm 0.88$ & $34.00^{\mathrm{b}} \pm 0.58$ & $45.33^{\mathrm{a}} \pm 1.20$ & $44.73^{\mathrm{a}} \pm 0.33$ & $42.23^{\mathrm{a}} \pm 1.20$ & $43.20^{a} \pm 0.33$ \\
\hline $\mathrm{LDL}(\mathrm{mg} / \mathrm{dl})$ & $20.31^{\mathrm{a}} \pm 7.35$ & $20.87^{\mathrm{a}} \pm 2.33$ & $17.67^{\mathrm{b}} \pm 7.62$ & $18.98^{b} \pm 0.58$ & $15.93^{\mathrm{b}} \pm 2.67$ & $14.16^{\mathrm{b}} \pm 1.73$ \\
\hline \multicolumn{7}{|l|}{ Antioxidant status } \\
\hline $\mathrm{TAC}(\mathrm{mM} / \mathrm{L})$ & $1.60^{\mathrm{c}} \pm 1.23$ & $1.72^{\mathrm{b}} \pm 1.57$ & $2.21^{\mathrm{a}} \pm 1.85$ & $2.24^{\mathrm{a}} \pm 2.56$ & $2.24^{\mathrm{a}} \pm 3.25$ & $2.27^{\mathrm{a}} \pm 2.28$ \\
\hline $\operatorname{MDA}(\mathrm{nmol} / \mathrm{ml})$ & $20.11^{\mathrm{a}} \pm 3.25$ & $19.19^{\mathrm{a}} \pm 6.18$ & $17.34^{\mathrm{b}} \pm 3.04$ & $17.11^{\mathrm{b}} \pm 5.47$ & $16.84^{\mathrm{b}} \pm 6.77$ & $16.20^{\mathrm{b}} \pm 8.22$ \\
\hline $\mathrm{GSP}(\mathrm{nmol} / \mathrm{ml})$ & $10.51^{\mathrm{c}} \pm 2.58$ & $11.92^{b} \pm 3.57$ & $12.37^{\mathrm{a}} \pm 4.12$ & $12.44^{\mathrm{a}} \pm 5.42$ & $12.50^{\mathrm{a}} \pm 4.36$ & $12.91^{\mathrm{a}} \pm 1.95$ \\
\hline
\end{tabular}




\section{Zeweil et al.}

The results showed insignificant differences between control and tylosin groups concerning triglycerides, total cholesterol, HDL and LDL. These results may due to the cinnamon inhibition mechanism of3-hydroxy-3-methylglutaryl-coenzyme A reductase (HMG-CoA reductase) activity. Two key enzymes involved in regulating cholesterol metabolism are HMG-CoA reductase, the rate-limiting enzyme in the cholesterol biosynthetic pathway and AcylCoA: cholesterolacyltransferase (ACAT), the cholesterol-esterifying enzyme in tissue. The inhibition of HMGCoAreductase decreases cholesterol synthesis and its inhibitors are very effective in lowering plasma cholesterol in most animal species, including humans (Alberts1988). Cinnamic acid $(0.02 \%, \mathrm{w} / \mathrm{w})$ and its synthetic derivatives (HPP304, HPP305) significantly inhibit hepatic HMG-CoA reductase activity and decrease serum total cholesterol level (Lee et al. 2001\& 2007). The present results were in agreement with those of Ciftci et al. (2010) reported that total cholesterol of the serum $(\mathrm{P} \leq 0.01)$, thigh and breast meat $(\mathrm{P} \leq 0.05)$ were found to be lower in both cinnamon groups (500 and $1000 \mathrm{ppm}$ of cinnamon oil). On the other hand, Lee et al. (2003) failed to show any hypocholesterolemic effects of the active items as cinnamaldehyde. Wientarsih et al. (2002) reported that Curcuma longa supplementation to the rabbit diets significantly decreased LDL, total cholesterol and triglycerides concentrations in plasma. Where, inclusion of Curcuma longa in the rabbit diets led to an increase in the 3-hydroxy3-methylglutaryl coenzyme reductase inhibitor activity (Wientarsih et al., 2002); thereby, the reduction of 3hydroxy-3-methylglutaryl coenzyme reductase resulted in a decrease in total cholesterol biosynthesis in rat cells (Amin et al., 1993). The obtained results were in agreement with Alagawany et al. (2016) who found that triglycerides, total cholesterol and low density lipoprotein concentrations were linearly and quadratically decreased with increasing the dietary proportion of turmeric. Also, Hussein (2013) clearly found that triglycerides and total cholesterol were significantly decreased with increasing turmeric levels to $7 \mathrm{~g} / \mathrm{kg}$ diet. The reduction of lipids profile (triglycerides, total cholesterol and low density lipoprotein concentrations) may be due to curcumin that enhances bile production and hence lipid digestion (Al-Sultan and Gameel, 2004). Asai and Miyazawa (2001) indicated that liver triacylglycerol and cholesterol concentrations were significantly lower in rats fed curcumin than in control animals. Plasma triacylglycerol in the very low-density lipoproteins fraction were also lower in curcumin fed rats. Hepatic acyl-CoA oxidase activity of the curcumin group was significantly higher than that of the control. The obtained results in the present study contrast with the results reported by Emadi et al. (2007) who demonstrated that turmeric supplementation into the basal diets of broilers significantly increased total cholesterol and HDLcholesterol and decreased LDL-cholesterol, but did not affect total triglycerides.

Table 5 presents the results on the effects of different supplementations on serum total antioxidant capacity, malondialdehyde and glutathione peroxidase concentrations of growing rabbits.

Rabbits exposed to high temperature conditions during summer season resulted in significant decrease $(\mathrm{P} \leq 0.05)$ in serum total antioxidant capacity (TAC) and glutathione peroxidase (GP) and significant increase in malondialdehyde (MDA), however, feeding rabbits phytogenic cinnamon and turmeric supplemented diet improved the TAC and antioxidant enzyme (GP) and reduced the MDA concentration in comparison with the control group. Antibiotic tylosin also significantly $(\mathrm{P} \leq 0.05)$ improved TAC and GP in comparison with control, however, the phytogenic feed additives was more effective than antibiotic. Our results are also supported by Benzie and Wachtel-Galor (2011) who reported that turmeric extract (1.66 mg/kg of body weight) given to rabbits fed a high-fat diet, oxidation of erythrocyte membranes was found to be significantly lower than that in membranes of control animals. Superoxide dismutase (SOD) "metalloprotein enzyme" is the first enzyme contributed in the antioxidant defense system. Glutathione Peroxidase (GSH-Px) "seleno enzyme" catalyses the reaction of hydro peroxides with reduced glutathione to form glutathione disulphide. Consequently, elevated levels of these enzymes may improve the steady state of antioxidant system of rabbits. Quiles et al. (2002) reported that supplementation with Curcuma longa reduces oxidative stress and attenuates the development of fatty streaks in rabbits fed a high cholesterol diet.

Supplementation of basal diet with cinnamon and turmeric could equally improve blood serum glotathion peroxidase in rabbits and were more effective than tylosin, as compared with control. Ashour et al. (2014) reported that antioxidant enzymes including GSH-Px and SOD are synthesized and regulated endogenously. The SOD plays an important role in protecting cells from damage caused by reactive oxygen species (ROS), but this process requires dietary supply of the appropriate nutrients (Ashouret al., 2014). Such antioxidant effects would be expected to improve the health of rabbits. From these results, it can be stated that supplementation with phytogenic additives as cinnamon or turmeric could be applied in the future to improve the nutritional quality of rabbit meat. It seems that cinnamon and turmeric supplementation to basal control diet was effective in enhancing the antioxidant ability of rabbits. These effects are due to the antioxidant property of turmeric and cinnamon (Balasubramanyam et al., 2003 and Lin et al. 2003). Reddy and Lokesh (1994) found that curcumin supplementation inhibited lipid peroxidation in rat liver microsomes, erythrocyte membranes and brain homogenates. Moreover, it lowered susceptibility of LDL to 
oxidation (Mesa et al., 2000). Ciftciet al (2010) reported that cinnamon oil (1000 ppm) reduced MDA level (P $\leq$ $0.05)$ and increased GSH-Px and catalase (CAT) activities $(\mathrm{P} \leq 0.01)$ in broiler chickens. These effects are due to the antioxidant property of cinnamon oil (Lin et al. 2003). The protective role of essential oils may result from its antioxidative defense mechanism through the induction of antioxidant enzyme activities (Hsu and Liu 2004). Choiem Hwang (2005) reported that the intake of medicinal plants in rats results in an increase in antioxidant enzyme activity and a decrease in MDA. Phenolic compounds of essential oils increased the activity of CAT, which in turn detoxifies hydrogen peroxide and converts lipid hydroperoxides to nontoxic substances (Fkiet al. 2005). In addition, GSH-Px and CAT activity were found to be lower in the antibiotic group compared with the other cinnamon groups and control of the present study $(P<0.001)$. Antibiotics produce different effects on CAT and GSH-Px activities in the organism (Johnson et al. 2000). Sukoyan et al. (2005) reported that penicillin, amino glycosides and cephalosporins decreased enzyme activity of the glutathione associated antioxidant system, after treatment with antibiotics glutathione peroxidase activity decreased, while catalase activity remained unchanged.

\section{CONCLUSIONS}

Based on experiment findings, we state that cinnamon and turmeric could have beneficial effects on performance, digestibility and were significantly an immunomodulatory and may be play an important role as an exogenous antioxidant.

\section{REFERENCES}

Alagawany, M., E. A. Ashour and F. M. Reda (2016). Effect of dietary supplementation of garlic (Allium sativum) and turmeric (Curcuma longa) on growth performance, carcass traits, blood profile and oxidative status in growing rabbits, Ann. Anim. Sci., Vol. 16 (2): 489-505.

Alberts, A. W. (1988): Discovery, biochemistry and biology of lovastatin. Am J of Cardiol 62: 10J-15J.

Al-Sultan, S. I. and A. A. Gameel (2004). Histopathological changes in the livers of broiler chicken supplemented with turmeric (Curcuma longa). Int. J. Poultry Sci., 3: 333-336.

Amin, D., S. K. Gustafson, J. M. Weinacht, S. A. Cornell, K. Neuenschwander, B. Kosmider and A. C. Scotese, J. R. Regan and M. H. Perrone(1993). RG12561 (dalvastatin): a novel synthetic inhibitor of HMG-CoA reductase and cholesterol-lowering agent. Pharmacology, 46: 13-22.

AOAC (2005).Official Methods of Analysis. $18^{\text {th }}$ Edn.Association of Official Analytical Chemist, International Maryland, USA.

Asai, A. and T. Miyazawa (2001). Dietary curcuminoids prevent high-fat diet-induced lipid accumulation in rat liver and epididymal adipose tissue. J. Nutr. 131, 2932-2935.

Ashour, E.A., M. Alagawany, F. M. Reda and M. E. Abdel-Hack (2014).Effect of supplementation of Yucca schidigera to growing rabbits diets on growth performance, carcass characteristics, serum biochemistry and liver oxidative status. Asian J. Anim. Vet. Adv., 9: 732-742.

Astawa, P. A., I.K. Budaarsa, I.K. Sumadi and I.G. Mahardik (2016). Additional Turmeric Powder (Curcuminoid) into Traditional Ration to Improve the Productivity of Bali Pig, International Research Journal of Engineering, IT and Scientific Research (IRJEIS) Vol. 2 (7): 28-33.

Babu, P. S. and K. Srinivasan (1997). Hypolipidemic action of curcumin, the active principle of turmeric (curcuma longa) in streptozotocin induced diabetic rats. Molecular and Cellular Biochemistry, 166: 169-175.

Baghban, K. P., M. Daneshyar and R. Najafi (2016). Effects of Cinnamon (Cinnamomumzeylanicum) and Turmeric (Curcuma longa) Powders on Performance, Enzyme Activity, and Blood Parameters of Broiler Chickens Under Heat Stress, Poultry Science Journal 4 (1): 47-53.

Balasubramanyam, M., A.S. Koteswari, R.F. Kumar, S.U. Monickaraj, J. Mahes-wari and V. Mohan (2003).Curcumin-induced inhibition of cellular reactive oxygen species generation: novel therapeutic implications. J. Biosci., 28: 715-721. 


\section{Zeweil et al.}

Basavaraj, M., V. Nagabhushana, N. Prakash, S. Mallikarjunappa, M. M. Appannavar and W. Prashanth (2010). Effect of dietary supplementation of Pulvis Curcuma Longa on the voluntary feed intake, nutrient digestibility and growth performance of broiler rabbits under summer stress. Vet. World, 3: 369-372.

Benzie, I. F. F. and S. Wachtei-Galor (2011). Herbal Medicine: Biomolecular and Clinical Aspects. $2^{\text {nd }}$ edition.pp. 277.

Bunn, H.F. and B.G. Forget (1986). Hemoglobin: Molecular, Genetic and Clinical Aspects. Saunders, Philadelphia

Chandrasekaran, C. V., K. Sundarajan, J. R. Edwin, G. M. Gururaja, D. Mundkinajeddu and A. Agarwal (2013). Immune-stimulatory and anti-inflammatory activities of Curcuma longa extract and its polysaccharide fraction.Pharmacognosy Research, 5: 71-79.

Chang, S. T., P. F. Chen, and S. C. Chang (2001). "Antibacterial activity of leaf essential oils and their constituents from Cinnamomumosmophloeum,” Journal of Ethnopharmacology, 77,(1): 123-127.

Cheeke, P. R. 1987. Rabbit feeding and nutrition. Oregon: Academic Press, 1987.

Choiem Hwang, J. K. (2005): Effect of some medicinal plants on plasma antioxidant system and lipid levels in rats. Phytoth Res 19: 382-386

Churchill, M., A. Chadburn, R. T. Bilinski and M. M. Bertagnolli (2000). Inhibition of intestinal tumors by curcumin is associated with changes in the intestinal immune cell profile. Journal of Surgical Research, 89: $169-175$.

Ciftci, M., U. G. Simsek, A. Yuce, O. Yilmaz and B. Dalkilic (2010). Effects of Dietary Antibiotic and Cinnamon Oil Supplementation on Antioxidant Enzyme Activities, Cholesterol Levels and Fatty Acid Compositions of Serum and Meat in Broiler Chickens, Acta Vet. Brno 79: 33-40.

Coles, E. H. (1986). Erythrocytes. In: Veterinary clinical pathology, 2nd ed. Saundal WB. Company, Philadelphia, London, Toronto. pp. 99-141.

Comito, R.W., W.O. Reece, D. W. Trampel and K.J. Koehler (2007).Acid-base balance of the domestic turkey during thermal panting. Poult. Sci. 86:2649-2652

Cunningham, J.G. and B.G. Klein (2007). Veterinary Physiology: 4th Ed. Saunders Elsevier 2007. pp: 347-447.

Dixit, V.P., P. Jain and S.C. Joshi (1988).Hypolipidaemic effects of Curcuma longa L. and Nardostachysjatamansi, DC in triton-induced hyperlipidaemic rats. Indian Journal of Physiology and Pharmacology. 32: 299-304.

Dorman, H. J. and S. G. Deans (2000). Antimicrobial agents from plants: Antibacterial activity of plant volatile oils. J. Appl. Microbiol. 88:308-316

Duncan, D.B. (1955). Multiple range and multiple F test, Biometrics 11:1-42.

Durrani, F.R., I. Mohammed, S. Asal, S. M. Shhail, C. Naila and Z. Durrani (2006). Effect of different levels of feed added turmeric (Curcuma longa) on the performance of broiler chicks. J. Agr. Biol. Sci. 1, 9-11.

El-Kholy, K. H., S.Z. El-Damrawy and T.S.T. Seleem (2012).Rabbit productivity and reproductively as affected by cinnamon (Cinnamomumzeylanicum). Egypt. Poult. Sci. Vol (32) (IV): 691-703.

Emadi, M.., H. Kermanshahi and E. Maroufyan (2007). Effect of varying levels of turmeric rhizome powder on some blood parameters of broiler chickens fed corn-soybean meal based diets. Int. J. Poultry Sci. 6, 345-348.

Fekete, S. and T. Gippert (1986).Digestibility and nutritive value of nineteen important feedstuffs for rabbits. J. Applied. Rabbit Res., 9 (3): 103-108.

Fki, I., M. Bouaziz, Z. Sahnoun and S. Sayadi (2005): Hypocholesterolemic effects of phenolic-rich extracts of Chemlali olive cultivar in rats fed a cholesterol-rich diet. Bioorg Med Chem 13: 5362-5370.

Hepler, O. E. (1966). Manual of Clinical Laboratory Methods.Thomas Spring Field. Illinois, $4^{\text {th }}$ edition, Vol 180: 389-392.

Hosseini-Vashan, S. J., A. Golian, A. Yaghobfar, A. Zarban, N. Afzali and P. Esmaeilinasab (2012). Antioxidant status, immune system, blood metabolites and carcass characteristic of broiler chickens fed turmeric rhizome powder under heat stress. African Journal of Biotechnology, 11: 16118-16125. 
Hsu, D. Z. and M. Y. Liu (2004): Sesame oil protects against lipopolysaccharide-stimulated oxidative stress in rats. Crit Care Med 32: 227-231.

Hussein, S. N. (2012). Effect of Turmeric (Curcuma longa) powder on growth performance, carcass traits, meat quality, and serum biochemical parameters in broilers. Journal of Advanced Biomedical and Pathobiology Research, 3: 25-32.

Hussein, S. N. (2013). Effect of turmeric (Curcuma longa) powder on growth performance, carcass traits, meat quality, and serum biochemical parameters in broilers. J. Adv. Biomed. Pathobiol. Res., 3: 25-32.

Jagetia, G. C. and B. B. Aggarwal (2007)."Spicing up" of the immune system by curcumin. Journal of Clinical Immunology, 27: 19-35.

Joe, E., U. J. S. P. Rao and B. R. Lokesh (1997). Presence of an acidic glycoprotein in the serum of arthritic rats: modulation by capsaicin and curcumin. Molecular and Cellular Biochemistry, 169: 125-134.

Johnson, R. M., G. Goyette, V. Ravindranath and S. Ho (2000): Red cells from glutathione peroxidase-1-deficient mice have nearly normal defenses against exogenous peroxides. Blood 96: 1985-1988.

Kamel, C. (2001). Tracing modes of action and the roles of plant extracts in non-ruminants. Pages 135-150 in Recent Advances in Animal Nutrition. P. C. Garnsworthy and J. Wiseman, ed. Nottingham University Press, Nottingham, UK

Kumari, P., M. K. Gupta, R. Ranjan, K. K. Singh and R. Yadava (2007).Curcuma longa as feed additive in broiler birds and its patho-physiological effects. Indian Journal of Experimental Biology, 45: 272-277.

Lee, J. S., M. S. Choi, S. M. Jeon, T. S. Jeong, Y. B. Park, M. K. Lee and S. H. Bok (2001): Lipid-lowering and antioxidative activities of 3,4-di $(\mathrm{OH})$-cinnamate and 3,4-di $(\mathrm{OH})$-hydrocinnamate in holesterol-fed rats. Clin Chim Acta, 314: 221-229.

Lee, K. W., H. Everts, H. J. Kappert, M. Frehner, R. Losa and A. C. Beynen (2003): Effects of dietary essential oil components on growth performance, digestive enzymes and lipid metabolism in female broiler chickens. $\mathrm{Br}$ Poult Sci., 44: 450-457.

Lee, M. K., Y. B. Park, S. S. Moon, S. H. Bok, D. J. Kim, T. Y. Ha, T. S. Jeong, K. S. Jeong and M. S. Choi (2007): Hypocholesterolemic and antioxidant properties of 3-(4-hydroxyl) propanoic acid derivatives in highcholesterol fed rats. Chemico-Biol Interactions 170: 9-19.

Lin, C. C., S. J. Wu, C. H. Chang and L. T. Nu (2003): Antioxidant activity of Cinnamomum cassia. Phytoth Res 17: 726-730.

Ludders, J. W. (2004). Respiration in birds. In: Dukes' Physiology of Domestic Animals. $12^{\text {th }}$ ed. W. O. Reece, ed. Cornell Univ. Press, Ithaca, NY.Pages 149-161.

Mastura, M., M. A. N. Azah, S. Khozirah, R. Mawardi and A. A. Manaf (1999). Antiradical and antidermatophytic activity of Cinnamomum species essential oils. Cytobios., 98, 17-23.

Mesa, M. D., M. C. Ramirez- Tortosa, C. M. Aguilera and A. Gil (2000). Nutritional and pharmacological effects of Curcuma longa L. extracts. Recent. Res. Devel. Nut, 3, p. 157.

Montes-Belmont, R. and M. Carvajal (1998).Control of Aspergillusflavusin maize with plant essential oils and their components. Journal of Food Protection, 61: 616-619.

Mountzouris, K. C., V. Paraskevas and K. Fegeros (2009). Phytogenic compounds in broiler nutrition. In: Steiner T. (Eds). Phytogenics in Animal Nutrition.Nottingham University Press. Nottingham. Pages, 97-110.

Naderi, M., M. R. Akbari, E. Asadi-Khoshoei, K. Khaksar and F. Khajali (2014). Effects of Dietary Inclusion of Turmeric (Curcuma longa) and Cinnamon (Cinnamomumverum) Powders on Performance, Organs Relative Weight and Some Immune System Parameters in Broiler Chickens, Poultry Science Journal 2 (2): 153-163.

Natt, M. P. and C. A. Herrick (1952).A new blood diluent for counting erythrocytes and leucocytes of the chicken. Poultry Science, 31, 735-738.

Nelson, N.A., N. Lakshmanan and S. J. Lamont (1995). Sheep red blood cell and Brucellaabortus antibody responses in chickens selected for multitraitimmunocompetence. Poultry Sci., 74:1603-1609. 


\section{Zeweil et al.}

Njidda, A. A., J. U. Igwebuike and C. E. Isidahomen (2006).Haematological Parameters and carcass characteristics of weaning rabbits fed grade levels of molasses. Global Journal of Agric. Sci., 5(7): 167-172.

Nofrarias, M., E. G. Manzanilla, J. Pujols, X. Gibert, N. Majo, J. Segales and J. Gasa (2006). Effects of spray-dried porcine plasma and plant extracts on intestinal morphology and on leukocyte cell subsets of weaned pigs. Journal of Animal Science, 84: 2735-2742.

NRC (1977).Nutrients Requirements of Domestic Animals. Nutrients Requirements of Rabbits. ${ }^{2}$ nd Edition. National Research Council, National Academy of Science. Washington, DC. USA.

Ogbuewu, I.P., Kadurumba, O.E., Okoli, I.C. and M.U. Iloeje (2013).Effects of ginger rhizome powder supplements and sex on hematological indices of prepuberal rabbits. Journal of Agricultural Technology 2013 Vol. 9(1): 11 19 Available online http://www.ijat-aatsea.com ISSN 1686-9141.

Ong-ard, L., K. Ngampong and K. Boonsong (2010). Antimicrobial activity of curcuminoids from Curcuma longa L. on pathogenic bacteria of shrimp and chicken. Kasetsart J. Nat. Sci. 44, 364- 371.

Peiretti, P. G., G. Masoero and G. Meineri (2011). Effects of replacing palm oil with maize oil and Curcuma longa supplementation on the performance, carcass characteristics, meat quality and fatty acid profile of the perirenal fat and muscle of growing rabbits. Animal, 5: 795-801.

Quiles, J. L., M. M. Dolores, C. L. Ramirez- Tortosa, C. M. Aguilera, M. Battino, A.Gil and M. C. Ramirez- Tortosa (2002). Curcuma longa extract supplementation reduces oxidative stress and attenuates aortic fatty streak development in rabbits. Arterioscler. Thromb., 22: 1225-1231.

Reddy, A. C. and B. R. Lokesh (1994).Studies on the inhibitory effects of curcumin and eugenol on the formation of reactive oxygen species and the oxidation of ferrous iron. Mol. Cell. Biochem., 137: 1-8.

Reece, W.O. (2009). Functional Anatomy and Physiology of Domestic Animals, ${ }^{4}$ th Ed. Wiley-Blackwell.

Sadeghi, G. H., A. Karimi, S. H. PadidarJahromi, T. Azizi and A. Daneshmand (2012).Effects of cinnamon, thyme and turmeric infusions on the performance and immune response in of 1- to 21-day-old male broilers, Rev. Bras. Cienc. Avic. Vol.14 (1): 15-20.

Samarasinghe, K., Wenk, C., Silva, K.F.S.T. and Gunasekera, J.M.D.M. (2003). Turmeric (Curcuma longa) root powder andmannanoligosaccharides as alternatives to antibiotics in broiler chicken diet. Asian-Australian Journal of Animal Science, 16:1495-1500

Shihabudeen, M. S. H., P. D. Hansi and K. Thirumurugan (2011).Cinnamon extract inhibits $\alpha$-glucosidase activity and dampens postprandial glucose excursion in diabetic rats. Nutr. Metab, 8, 46.

Sirosis, M. (1995).Veterinary clinical laboratory procedure. Mosby year book, Inc. St. Louis, Missouri, USA.

Soliman, K. M. and R. I. Badeaa (2002). Effect of oil extracted from some medicinal plants on different mycotoxigenic fungi. Food and Chemical Toxicology, 40: 1669-1675.

Song-Oh, F., H. Li, J. Sun, and S. Wang (2013)."Protective effects of cinnamic acid and cinnamic aldehyde on isoproterenol-induced acute myocardial ischemia in rats," Journal of Ethnopharmacology, vol. 150, no. 1, pp. $125-130$.

South, E. H., J. H. Exon and K. Hendrix (1997). Dietary curcumin enhances antibody response in rats. Immunopharmacology and Immunotoxicology, 19: 105-119.

SPSS., (2001). Statistical software package for the social secinces. SPSS Inc. United States of America.

Sukoyan, G. V., M. R. Mumladze, E. D. Obaladze and N. A. Varazanashvili (2005): In vitro effects of gentamisin, ampicillin and cefobid and energy supply and antioxidant protection systems of venous blood erythrocytes in newborns. Bull Exp Biol Med 139, No. 6.

Szabóová R, Lauková A, Chrastinová L', Simonová M, Strompfová V, Haviarová M, Plachá I, Faix Š, Vasilková Z, Chrenková M and, Rafay J (2008).Experimental application of sage in rabbit husbandry. Acta Vet Brno 77: 581-588.

Tabak, M., R. Armon and I. Neeman (1999). Cinnamon extracts inhibitory effect on Helicobacter pylori. Journal of Ethnopharmacology, 67: 269-277. 
Wegmann, T.G. and O. Smithies (1966).A simple hemagglutination system requiring small amount of red cells and antibodies. Transfusion, 6: 67-73.

Wei, A. and T. Shibamoto (2007).Antioxidant activities and volatile constituents of various essential oils. Journal of Agricultural and Food Chemistry, 55: 1737-1742.

Wientarsih, I., S. Chakeredza and U. Meulen (2002). Influence of curcuma (Curcuma xanthorrhizaRoxb) on lipid metabolism in rabbits. J. Sci. Food Agr., 82: 1875-1880.

Wuthi-Udomler, M., W. Grisanapan, O. Luanratana and W. Caichompoo (2000). Anti-fungal activities of plant extracts. Southeast Asian J. Trop. Med. Public Health 2000; 31, Suppl., 1:178-82.

Zeweil, H. S., S. M. Zahran, M. H. Ahmed, Y. El- El-Gindy and W. G. M. Shaglouf (2016).Effects of allicin and lycopene on performance, carcass, hematological profile and antioxidant status of growing rabbits through summer season. Journal of the Advances in Agricultural Researches, 21 (4): 622-637.

تأثير الاضافة الغذائية للقرفة والكركم على صفات الأداء،صفات الأبيحة، الاستجابة المناعية الامية وميتابوليزم سيرم الام فى الأرانب النامية

\author{
حسن صابر زويل، سليمان محم زهران، محمد حسن أحمد، ياسمين مؤمن الجندي، نجاه سعد محمد خشيرة \\ قسم الانتاج الحيواني والسمكى - كلية الزراعة سابا باثا - جامعة الاسكندرية - الاسكندرية.
}

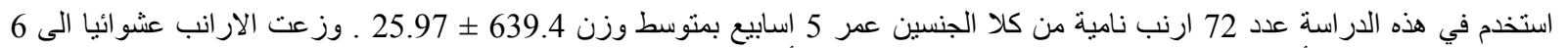

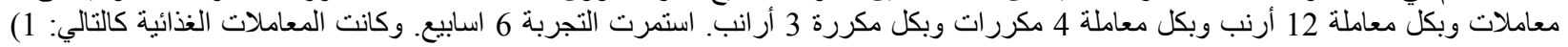

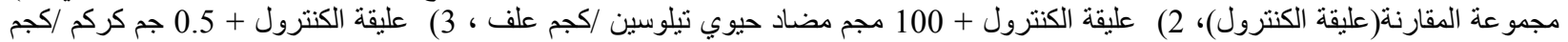

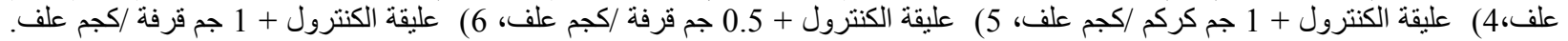

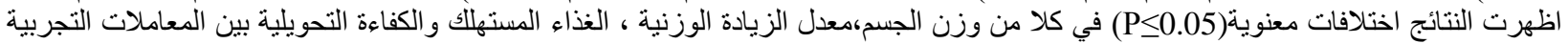

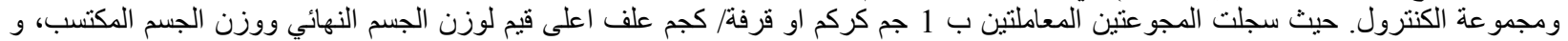

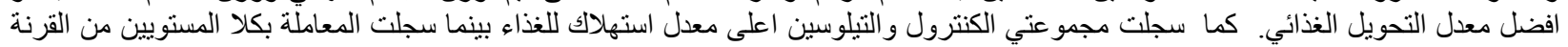

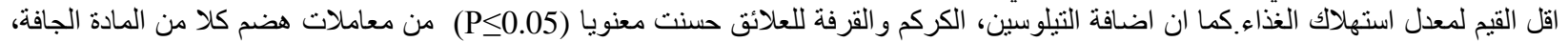

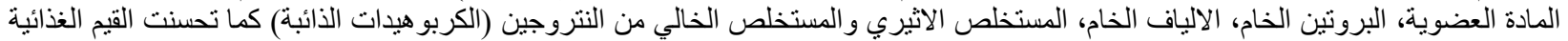

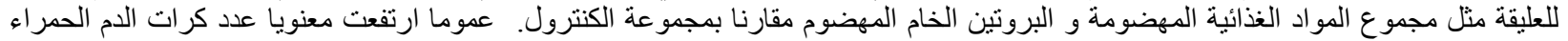

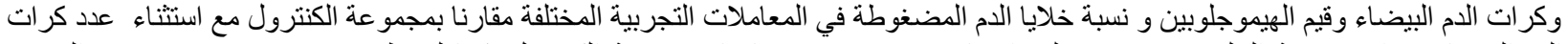

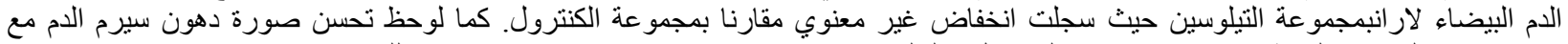

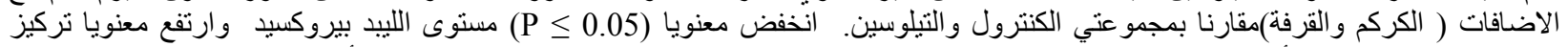

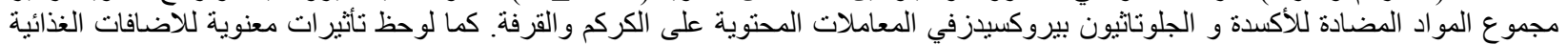

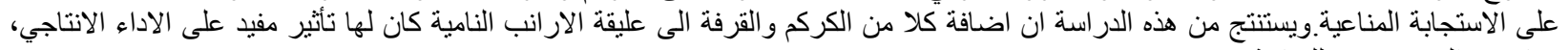
معاملات الهضم ورفع للمناعة. 